\title{
Effects of Soil Moisture and Fertilization Treatments on the Agronomic Traits of Teff (Eragrosis tef) in Southern Kyushu, Japan
}

\author{
Sachiko Idota*, Yasuyuki Ishii, Kiichi Fukuyama \\ Faculty of Agriculture, University of Miyazaki, Miyazaki, Japan \\ Email: ${ }^{*}$ sidota@cc.miyazaki-u.ac.jp, yishii@cc.miyazaki-u.ac.jp, a0e216@cc.miyazaki-u.ac.jp
}

Received 31 July 2015; accepted 20 September 2015; published 23 September 2015

Copyright (C) 2015 by authors and Scientific Research Publishing Inc.

This work is licensed under the Creative Commons Attribution International License (CC BY). http://creativecommons.org/licenses/by/4.0/

(c) $\underset{\mathrm{EY}}{(0)}$ Open Access

\section{Abstract}

This study investigated the agronomic characteristics of pot-cultured teff (Eragrostis tef) under soil moisture and fertilization treatments in southern Kyushu, Japan. In experiments examining the effects of soil moisture and fertilization, growth of teff and Setaria (Setaria sphacelata) as a reference species was compared under six treatments combining two soil moisture regimes, control (C) and high moisture $(\mathrm{H})$ treatment, and three fertilizer applications, chemical fertilizer with manure (CF + M), chemical fertilizer (CF) and doubled level of manure (DM). H treatment did not decrease dry matter yield in teff two months after transplanting, except when combined with CF + M, compared with a decreasing tendency in Setaria. Top and underground dry matter yields and harvest index in teff increased significantly $(P<0.05)$ under $H$ conditions with $D M$ application. In experiments examining the effect of $\mathrm{CF}$ application level, growth of teff was compared under four CF levels $\left(3.1,6.2,12.4\right.$ and $\left.24.8 \mathrm{gN} \mathrm{m}^{-2}\right) ; 6.2 \mathrm{gN} \mathrm{m}^{-2}$ is the standard level in the USA. Dry matter yield in teff did not differ significantly $(P>0.05)$ at CF application levels above $6.2 \mathrm{gN} \mathrm{m}^{-2}$ two months after sowing, suggesting that the optimum CF level of teff in southern Kyushu was comparable with that in the USA, and that teff had potential as an early-harvest forage crop two months after planting to replace summer forage in paddy fields of this region.

\section{Keywords}

Chemical Fertilizer, Eragrosis tef, Setaria sphacelata, Soil Moisture Regime, Manure

\section{Introduction}

In developing countries, consumption of animal products has increased remarkably [1], and thus, demand for li-

${ }^{*}$ Corresponding author.

How to cite this paper: Idota, S., Ishii, Y. and Fukuyama, K. (2015) Effects of Soil Moisture and Fertilization Treatments on the Agronomic Traits of Teff (Eragrosis tef) in Southern Kyushu, Japan. Agricultural Sciences, 6, 1003-1013.

http://dx.doi.org/10.4236/as.2015.69095 
vestock feed has also increased. Booming demand in the world's most rapidly growing economies for livestock products has led to a rapid increase in livestock production, which has mainly been supported by technological innovations and structural changes in the livestock sector [2]. Global temperature is expected to rise from 1.1 to $6.4^{\circ} \mathrm{C}$ (average of $3.0^{\circ} \mathrm{C}$ ) by 2100 , as predicted by IPCC, and the increased temperature will likely reduce the global food production potential [3]. The arable land area of the world is decreasing by around 700 million ha, while desertification is now proceeding on more than 5 million ha of land per year. In the future, intensive animal herbage production will be needed on more limited arable land than currently available.

A multiple cropping system is the most intensive farming practice in an agro-ecosystem, and is conducted in several countries [4] [5], occupying nearly $50 \%$ of arable land in China [6]. A double cropping system, composed of summer crops (e.g. maize and sorghum) cultivated from late March to early September, and winter crops (e.g. Italian ryegrass and oat) from mid-October to the following May, is quite common in southern Kyushu, Japan. Recently, forage rice production has replaced the cultivation of summer forage crops [7]. However, the Japanese self-sufficiency ratio for concentrated feed and roughage is now as low as $12 \%$ and $77 \%$, respectively [8], and total digestible nutrient (TDN)-based herbage supply is now decreasing year by year. Therefore, development of a novel cropping system including high-calorie and high-yielding forage crops is urgently needed to improve the self-sufficiency rate for animal feed.

Teff (Eragrostis tef) is a warm-season annual grass originating from Ethiopia, where teff is a staple crop [9]-[11], and field experiments have been conducted to evaluate the effects of irrigation and water stress on teff yield [12]-[14]. The grass can be cultivated in a wide range of soil and environmental conditions, and is tolerant to both drought and water-logging [15] [16]. Teff was recently introduced to several countries, such as the USA, Australia, India and African countries neighboring Ethiopia. The grass has been examined for the use as a forage crop supplied to livestock (horses and cattle), and cultivation just started in the USA [17]-[19]. Eco-physiological properties of teff include quick emergence and early maturation potential [20], which allows harvest of the grass at the early booting stage, 45 to 55 days from sowing. Teff can be cultivated as a relief crop when other forage crops fail to be established. Teff has been evaluated as adequate for a rotational crop in the USA, since the grass has a fine- and shallow-rooting system [19]. However, the grass is quite new to cultivation in southern Kyushu, Japan. Therefore, it is necessary to determine the adaptability of the grass to humid soil conditions and the responses of herbage growth and quality to fertilizer supply from chemical and organic manure. Southern Kyushu is a major area for animal production in Japan, and thus, it is necessary to promote utilization of the animal manure.

In the current study, we estimated the agronomic characteristics of teff as affected by soil moisture stress and fertilizer supply in southern Kyushu, Japan.

\section{Materials and Methods}

\subsection{Response to Soil Moisture Content and Chemical and Organic Manure Supply (Experiment 1)}

\subsubsection{Cultivation and Treatment}

This experiment was carried out in a plastic house at the University of Miyazaki in southern Kyushu, Japan $\left(31^{\circ} 82^{\prime} \mathrm{N}, 131^{\circ} 40^{\prime} \mathrm{E}\right)$ in 2012. Teff (cv. Tiffany) and Setaria (Setaria sphacelata, line KSG0801) were sown to soil-filled containers sized at $30 \mathrm{~cm} \times 50 \mathrm{~cm} \times 20 \mathrm{~cm}$ (depth) on 6 August 2012, and three nursery plants (3 - 5 leaf stage) were transplanted into Wagner pots ( $500 \mathrm{~cm}^{2}$ area) filled with heavy clay soil and peat moss at 10:1 (v/v) on 7 September 2012. The pots were set in a plastic bucket $50 \mathrm{~cm}$ in diameter and $40 \mathrm{~cm}$ high to regulate soil moisture content and were placed at a density of 4 pots $\mathrm{m}^{-2}$. Treatments included two soil moisture levels and three fertilizing regimes in a randomized block design with three replications. The soil water levels were adjusted by watering to $-30 \mathrm{~cm}(\mathrm{C})$ and $-10 \mathrm{~cm}(\mathrm{H})$ below the soil surface every afternoon for 69 days from 7 September (transplanting date) to 15 November 2012 (harvesting date). Plants were supplied a single dose of one of three fertilizing regimes, chemical fertilizer and organic manure (Global Yuuki; Hazama farm, Miyazaki, Japan) $(C F+M)$, chemical fertilizer (CF) and a double level of organic manure (DM). DM treatment was installed for promoting the utilization of animal manure. The rate of elements (in $\mathrm{g} \cdot \mathrm{m}^{-2}$ ) in the fertilizers differed among treatments, with CF $+\mathrm{M}$ and CF applied at the same rate of 18.5, 44.3 and 55.2 of $\mathrm{N}_{2} \mathrm{P}_{2} \mathrm{O}_{5}$ and $\mathrm{K}_{2} \mathrm{O}$, respectively, and DM treatment at 27.9, 73.7 and 103.5 of $\mathrm{N}, \mathrm{P}_{2} \mathrm{O}_{5}$ and $\mathrm{K}_{2} \mathrm{O}$. 


\subsubsection{Measurement}

Soil moisture content and soil electrical conductivity (EC) were measured every other week by a soil moisture meter (Moisture Meter type HH2, Delta-T Devices, Cambridge, United Kingdom), which was inserted at a soil level of $-10 \mathrm{~cm}$. Soil organic matter (OM) content was measured on air-dried soil passed through a $2 \mathrm{~mm}$ screen by an ignition loss method. Plants were measured for growth attributes such as plant height, plant length, leaf number, tiller number and SPAD index (SPAD 502 meter, Minolta, Osaka, Japan) two months after transplanting on 15 November 2012. Plants were cut at the soil level to measure fresh and dry weight of aboveground parts, and underground parts were sampled after washing with water. Aboveground and underground plant parts were ground to pass through a $1 \mathrm{~mm}$ screen and were analyzed for in vitro dry matter digestibility (IVDMD) [21], total nitrogen (TN) and total carbon (TC). The harvest index of teff was determined by calculating ear dry matter weight divided by total dry matter weight $\times 100$.

\subsection{Response to the Rate of Chemical Fertilizer (Experiment 2)}

\subsubsection{Cultivation and Treatment}

This experiment was carried out in a plastic house at the University of Miyazaki in southern Kyushu, Japan $\left(31^{\circ} 82^{\prime} \mathrm{N}, 131^{\circ} 40^{\prime} \mathrm{E}\right)$ in 2014 . Teff (cv. Tiffany) was sown to Wagner pots $\left(500 \mathrm{~cm}^{2}\right.$ area) filled with heated soil (Miyazaki, Japan) on 15 July 2014. Pots were watered every afternoon throughout the experiment. Treatments included four levels of chemical fertilizer supplied in a randomized block design with three replications. The standard chemical fertilizer (abbreviated as S) level for teff was determined as $6.2 \mathrm{~g} \cdot \mathrm{m}^{-2}$ each of $\mathrm{N}, \mathrm{P}_{2} \mathrm{O}_{5}$ and $\mathrm{K}_{2} \mathrm{O}$ in the USA [22]. Therefore, plants were supplied with a single basal dose of chemical compound fertilizer (14:14:14 of N, $\mathrm{P}_{2} \mathrm{O}_{5}$ and $\mathrm{K}_{2} \mathrm{O}$ (\%), Sumitomo Chemical Company, Ltd., Tokyo, Japan) at four fertilizer levels $\left(1 / 2 \mathrm{~S}, 3.1 \mathrm{~g} \cdot \mathrm{m}^{-2}\right.$; $\mathrm{S}, 6.2 \mathrm{~g} \cdot \mathrm{m}^{-2} ; 2 \mathrm{~S}, 12.4 \mathrm{~g} \cdot \mathrm{m}^{-2}$ and $4 \mathrm{~S}, 24.8 \mathrm{~g} \cdot \mathrm{m}^{-2}$ each of $\mathrm{N}, \mathrm{P}_{2} \mathrm{O}_{5}$ and $\left.\mathrm{K}_{2} \mathrm{O}\right)$.

\subsubsection{Measurement}

Soil samples were air-dried and ground to pass through a 20-mesh sieve. Soil pH was measured by a glass electrode method and soil EC was measured by a platinum electrode method. Plants were measured for growth attributes such as plant length, tiller number and SPAD index using a SPAD 502 meter (Minolta) every 30 days after sowing. Plants were cut at soil level and measured for fresh and dry weights. Plants were ground to pass through a $1 \mathrm{~mm}$ screen and analyzed for IVDMD and TN content. Total nitrogen was measured by the Kjeldahl method and crude protein (CP) content was calculated by the TN content multiplied by 6.25 .

\subsection{Statistical Analysis}

Analysis of variance was performed using Excel Statistics (OMS Co. Ltd., Saitama, Japan). Differences in mean values were assessed at the 5\% probability level using the Tukey-Kramer method in Experiment 1 and the Bonferroni multiple comparison procedure in Experiment 2.

\section{Results}

\subsection{Response to Soil Moisture Content and Chemical and Organic Manure Supply (Experiment 1)}

\subsubsection{Characteristics of Soil Environment}

Changes in soil moisture content and EC were observed during the experimental period (Figure 1). Soil moisture content was higher in the $\mathrm{H}$ treatment, averaging $54.7 \% \pm 0.6 \%$, than in the $\mathrm{C}$ treatment, $42.5 \% \pm 0.8 \%$, and both species was lowest in the C-DM plot of Setaria. Soil EC had two types across treatments, in the C-CF + M, C-DM and H-DM treatments, with EC values greater than $600 \mathrm{mS} \cdot \mathrm{m}^{-1}$ and with lower values of 300 to 500 $\mathrm{mS} \cdot \mathrm{m}^{-1}$ for both grasses in other treatments. Across fertilizer treatments, EC was the highest in DM, followed by $\mathrm{CF}+\mathrm{M}$ and $\mathrm{CF}$ at harvest for both grasses, and EC was generally higher in $\mathrm{C}$ treatments than $\mathrm{H}$ treatments across moisture treatments. Soil OM content was highest in DM, followed by CF + M and CF before cultivation. A decrease in OM content at harvest was common among treatments for both grasses, except for H-CF treatments, and the rate of decrease was highest in the DM, followed by the CF + M and CF treatments for both moisture treatments of both grasses, except for C-DM in Setaria (Table 1). 

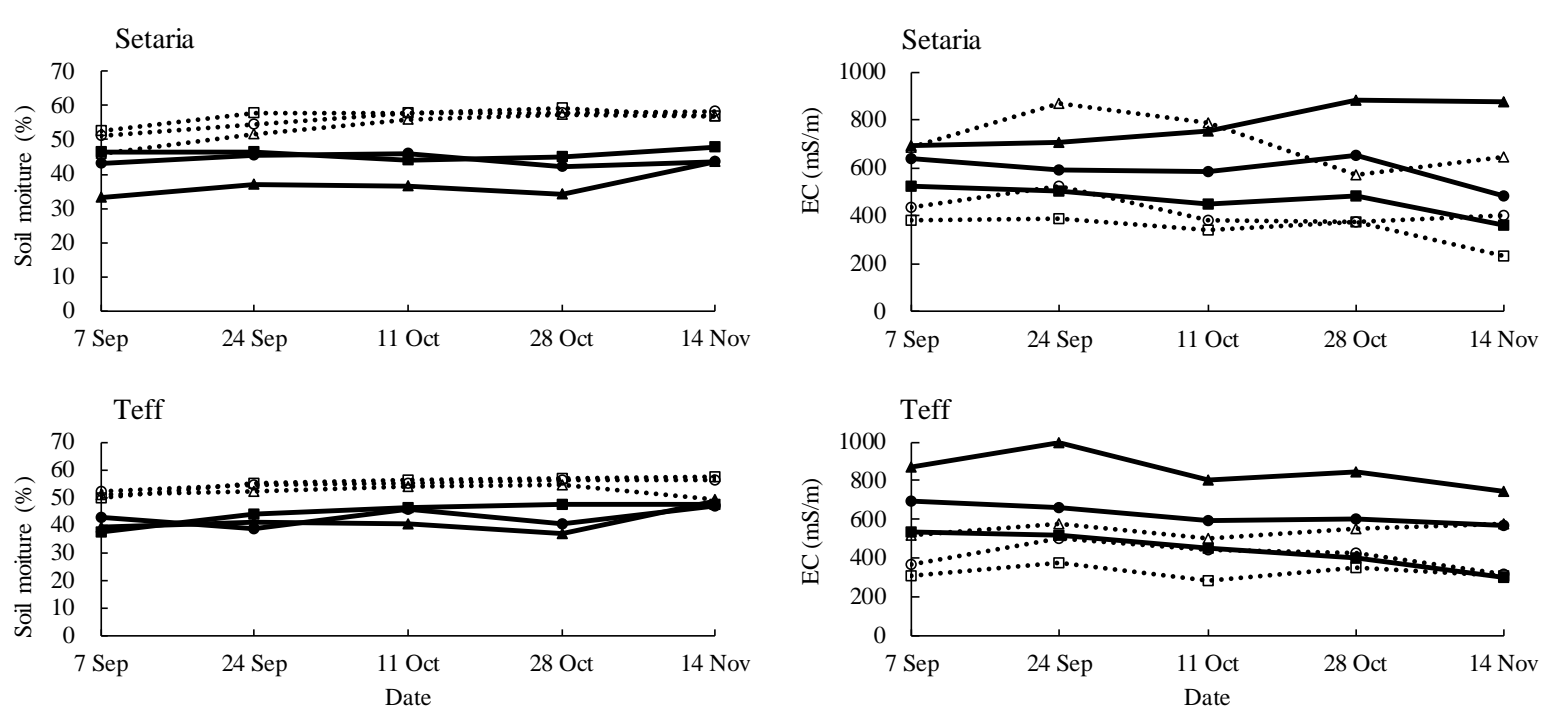

Figure 1. Changes in soil moisture content and electrical conductivity (EC) in several soil moisture and fertilization treatments (Exp. 1). Soil moisture: Control (C); high moisture (H) treatment; Fertilization: Chemical fertilizer (CF); chemical fer-

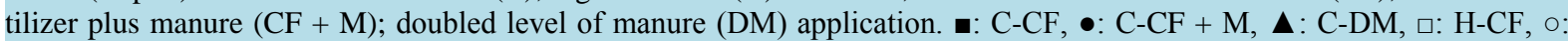
$\mathrm{H}-\mathrm{CF}+\mathrm{M}, \triangle \mathrm{S}$ H-DM.

Table 1. Soil organic matter content (\%DM) under soil moisture and fertilization treatments at the end of the experiment (Exp. 1).

\begin{tabular}{cccccc}
\hline \multirow{2}{*}{ Fertilization } & \multirow{2}{*}{ Culture soil } & \multicolumn{2}{c}{ Setaria } & \multicolumn{2}{c}{ Teff } \\
\cline { 3 - 6 } & & Control & High moisture & Control & High moisture \\
\hline CF & 17.4 & $14.7(85)$ & $19.1(110)$ & $15.7(90)$ & $14.7(84)$ \\
CF + M & 23.4 & $19.1(81)$ & $18.2(78)$ & $19.5(83)$ & $17.3(74)$ \\
DM & 24.1 & $17.6(73)$ & $17.8(74)$ & $21.4(89)$ & $17.5(73)$ \\
\hline
\end{tabular}

Figures in parentheses show soil organic matter content in each treatment relative to that in culture soil (\%). For details on fertilization, refer to the footnote for Figure 1.

\subsubsection{Characteristics of Plant Growth Attributes}

Under the $\mathrm{C}$ moisture treatment, total plant dry matter weight tended to be higher in the CF + M and DM treatments than CF treatments for both grasses. Under $\mathrm{H}$ moisture treatment, plant dry matter weight tended to decrease in Setaria, while it tended to increase in teff, except for the great decrease in CF + M treatment of teff (Figure 2). These changes in total plant dry matter weight were mainly due to the stem fraction in Setaria, while due to both stem and ear fractions in teff, especially the great increase in ear dry matter weight in the H-DM treatment (Figure 2), which corresponded with the increase in harvest index in this treatment. Teff is a small cereal, and high nutritive value would be expected from the grain portion if harvested at the dough stage. The harvest index of teff was variable in the range $28 \%$ - 38\% in the $\mathrm{H}$ treatment and $31 \%$ - 36\% in the C treatment. The higher harvest index in the CF treatment for both moisture regimes of teff was reflected by a smaller plant biomass, and thus was not derived from the increase in ear dry weight.

In Setaria, compared with the $\mathrm{C}$ treatment, the $\mathrm{H}$ treatment had a lower leaf dry matter weight, which corresponded with a decrease in leaf number, and stem dry matter weight was also lower, corresponding with a decrease in tiller number. However, in teff, leaf number and tiller number did not significantly differ in different soil moisture regimes, except for the great decrease in the $\mathrm{H}-\mathrm{CF}+\mathrm{M}$ treatment.

The underground dry matter weight of teff was much lower than Setaria across fertilization and moisture treatments (Table 2). In the $\mathrm{H}$ treatment, the underground dry matter in Setaria tended to be lower, except for a slight increase in the H-CF + M treatment, while in teff, it tended to be higher, except for a decrease in the $\mathrm{H}-\mathrm{CF}+\mathrm{M}$ treatment. Photosynthetic assimilate transport among plant fractions might be different for Setaria and 


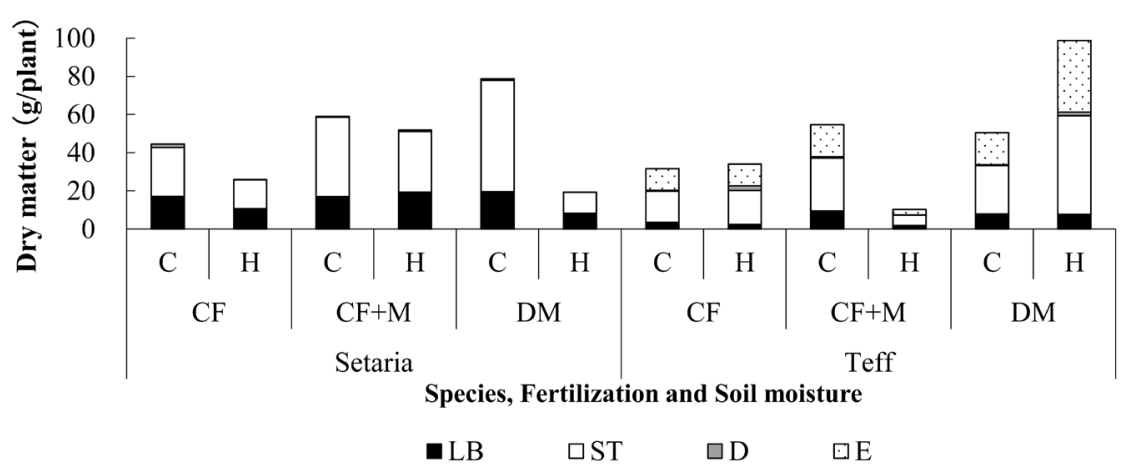

Figure 2. Dry matter of plant fractions in Setaria sphacelata (Setaria) and Eragrosis tef (teff) in several soil moisture and fertilization treatments (Exp.1). Plant fraction: leaf blade (LB), stem including leaf sheath (ST), dead parts (D), ear (E). Soil moisture: Control (C); high moisture (H); Fertilization: Chemical fertilizer (CF); chemical fertilizer plus manure $(\mathrm{CF}+\mathrm{M})$; doubled level of manure (DM).

teff. Therefore, the top-root ratio was higher in teff than in Setaria and tended to decrease from the C to H treatment in both grasses (Table 2). The higher top-root ratio in teff might reflect the annual habit of teff, compared with the perennial habit of Setaria [23].

\subsubsection{Quality of Forage}

The CP content tended to be lower in the $\mathrm{H}$ treatment for all fertilizer regimes in both grasses, except for an increase in the H-DM treatment of Setaria (Figure 3(a)). In teff, CP content tended to increase from the CF to CF $+\mathrm{M}$ and DM treatments in the $\mathrm{C}$ treatment, mainly due to the increase in leaf blade and ear CP content, while the $\mathrm{CP}$ content did not differ significantly among fertilizer treatments in the $\mathrm{H}$ treatment. In Setaria, the CP content showed no correlation with fertilizer application, with CP content highest in the CF + M treatment under C treatment, and highest in the DM treatment under $\mathrm{H}$ treatment, mainly due to the increase in leaf blade CP content.

Plant IVDMD in Setaria exceeded $600 \mathrm{mg} \cdot \mathrm{g}^{-1}$ in all moisture and fertilizer treatments and did not differ significantly among treatments (Figure 3(b)). In teff, IVDMD exceeded $500 \mathrm{mg} \cdot \mathrm{g}^{-1}$ and did not differ significantly among treatments, except for the H-CF treatment; while IVDMD was generally lower than in Setaria, this seemed to be due to lower stem IVDMD, reflected by stem elongation of the grass before harvest.

\subsection{Response to the Rate of Chemical Fertilizer (Experiment 2)}

\subsubsection{Characteristics of Soil Chemical Environment}

Soil $\mathrm{pH}$ tended to increase with time within a range of 5.2 to 5.8 among all fertilizer treatments. Soil EC decreased with time, and in August, increased with rate of fertilizer application, being highest in the 4S treatment, followed by the $2 \mathrm{~S}, \mathrm{~S}$ and $1 / 2 \mathrm{~S}$ treatments (Table 3).

\subsubsection{Characteristics of Plant Growth Attributes}

Plant length of teff tended to decrease with an increase in fertilizer application every month (Figure 4). Tiller number and SPAD index of teff increased with an increase in fertilizer application every month (Figure 4). The dry matter yield tended to increase with an increase in fertilizer application, while the difference among treatments was not significant in August or September. The growth rate of teff appeared larger from August to September than thereafter (Figure 5).

\subsubsection{Quality of Forage}

The CP content in every plant fraction of teff increased with an increase in fertilizer application in both September and October, being highest in the $4 \mathrm{~S}$ treatment (Figure 6). In this experiment, CP content of the leaf blade in the $4 \mathrm{~S}$ treatment was more than $150 \mathrm{mg} \cdot \mathrm{g}^{-1}$ in September and $200 \mathrm{mg} \cdot \mathrm{g}^{-1}$ in October, suggesting that the leaf blade is responsive to chemical fertilizer application. 
Table 2. Underground dry matter and top-root ratio of Setaria sphacelata (Setaria) and Eragrosis tef (teff) grown in several soil moisture and fertilization treatments (Exp. 1).

\begin{tabular}{|c|c|c|c|c|c|}
\hline \multirow{2}{*}{ Species } & \multirow{2}{*}{ Fertilization } & \multicolumn{2}{|c|}{ Underground dry matter (g/plant) } & \multicolumn{2}{|c|}{ Top-root ratio } \\
\hline & & Control & High moisture & Control & High moisture \\
\hline \multirow{3}{*}{ Setaria } & $\mathrm{CF}$ & 19.4 & 15.2 & 2.3 & 1.7 \\
\hline & $\mathrm{CF}+\mathrm{M}$ & 18.0 & 23.8 & 3.3 & 2.2 \\
\hline & DM & 23.9 & 9.3 & 3.3 & 2.1 \\
\hline \multirow{3}{*}{ Teff } & $\mathrm{CF}$ & 4.8 & 6.7 & 6.6 & 5.1 \\
\hline & $\mathrm{CF}+\mathrm{M}$ & 4.9 & 3.8 & 11.3 & 2.7 \\
\hline & DM & 4.1 & 8.5 & 12.4 & 11.7 \\
\hline
\end{tabular}

For details on fertilization, refer to the footnote for Figure 1.

Table 3. Soil pH and electric conductivity (EC) under several rates of fertilization (Exp. 2).

\begin{tabular}{|c|c|c|c|c|c|c|}
\hline \multirow{2}{*}{ Fertilization } & \multicolumn{3}{|c|}{$\mathrm{pH}$} & \multicolumn{3}{|c|}{$\mathrm{EC}\left(\mu \mathrm{S} \cdot \mathrm{cm}^{-1}\right)$} \\
\hline & 18 Aug. & 18 Sep. & 17 Oct. & 18 Aug. & 18 Sep. & 17 Oct. \\
\hline $1 / 2 \mathrm{~S}$ & 5.3 & 5.5 & 5.8 & 186.0 & 128.3 & 68.8 \\
\hline $\mathrm{S}$ & 5.5 & 5.7 & 5.8 & 215.1 & 122.1 & 86.7 \\
\hline $2 \mathrm{~S}$ & 5.4 & 5.6 & 5.8 & 362.3 & 92.9 & 116.7 \\
\hline $4 S$ & 5.2 & 5.4 & 5.7 & 615.3 & 186.8 & 117.0 \\
\hline
\end{tabular}

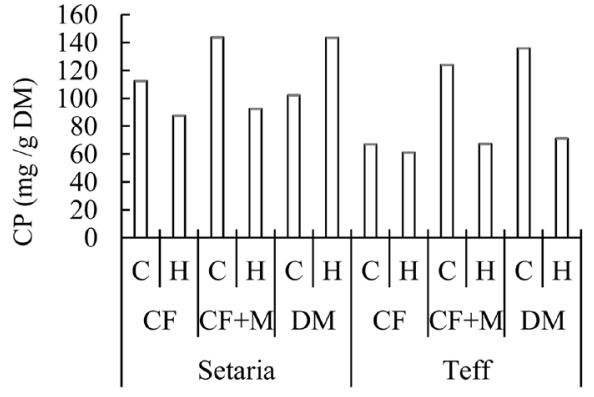

Species, fertilization and soil moisture

(a)

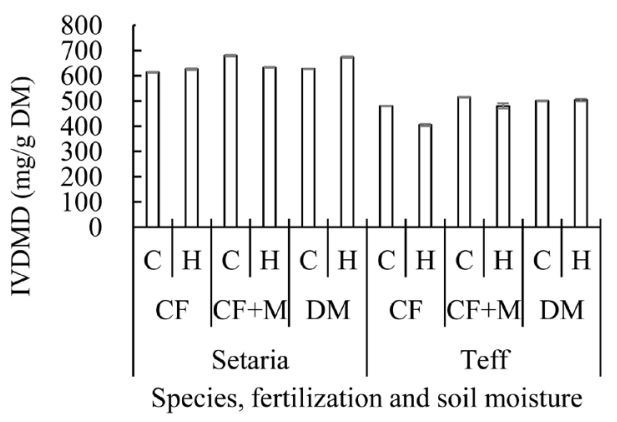

(b)

Figure 3. Crude protein (CP) content and in vitro dry matter digestibility (IVDMD) of Setaria sphacelata (Setaria) and Eragrosis tef (teff) in several soil moisture and fertilization treatments (Exp. 1). For details on fertilization, refer to the footnote for Figure 1.

\section{Discussion}

Teff grows well in a wide range of soil pH conditions, ranging from acid to alkaline [22], which fit our observations of good growth from $\mathrm{pH} 5.2$ to 5.8. However, this crop is unable to grow in extreme acid or alkaline environments [22]. In this study, the underground water level in the $\mathrm{H}$ treatment in Experiment 1 was closer to the soil surface than in a normal rotational upland field. Therefore, the pot soil environment in the $\mathrm{H}$ treatment was presumably under reductive and anaerobic conditions, which might reduce the immobilization rate of manure in the soil. The immobilization and mineralization rates of manure in paddy soil are reportedly higher than in the rotational upland fields [24]. In contrast, soil moisture content in the C treatment in Experiment 1 was similar to that in upland soil, where the immobilization of manure is promoted. As a result, soil organic matter content in the $\mathrm{H}$ treatment was decreased by promoting mineralization of manure during growth of teff.

Teff appears sensitive to day length [22], and the growth rate of teff decreased rapidly from October to November with the decrease in day length combined with the decrease in air temperature. 

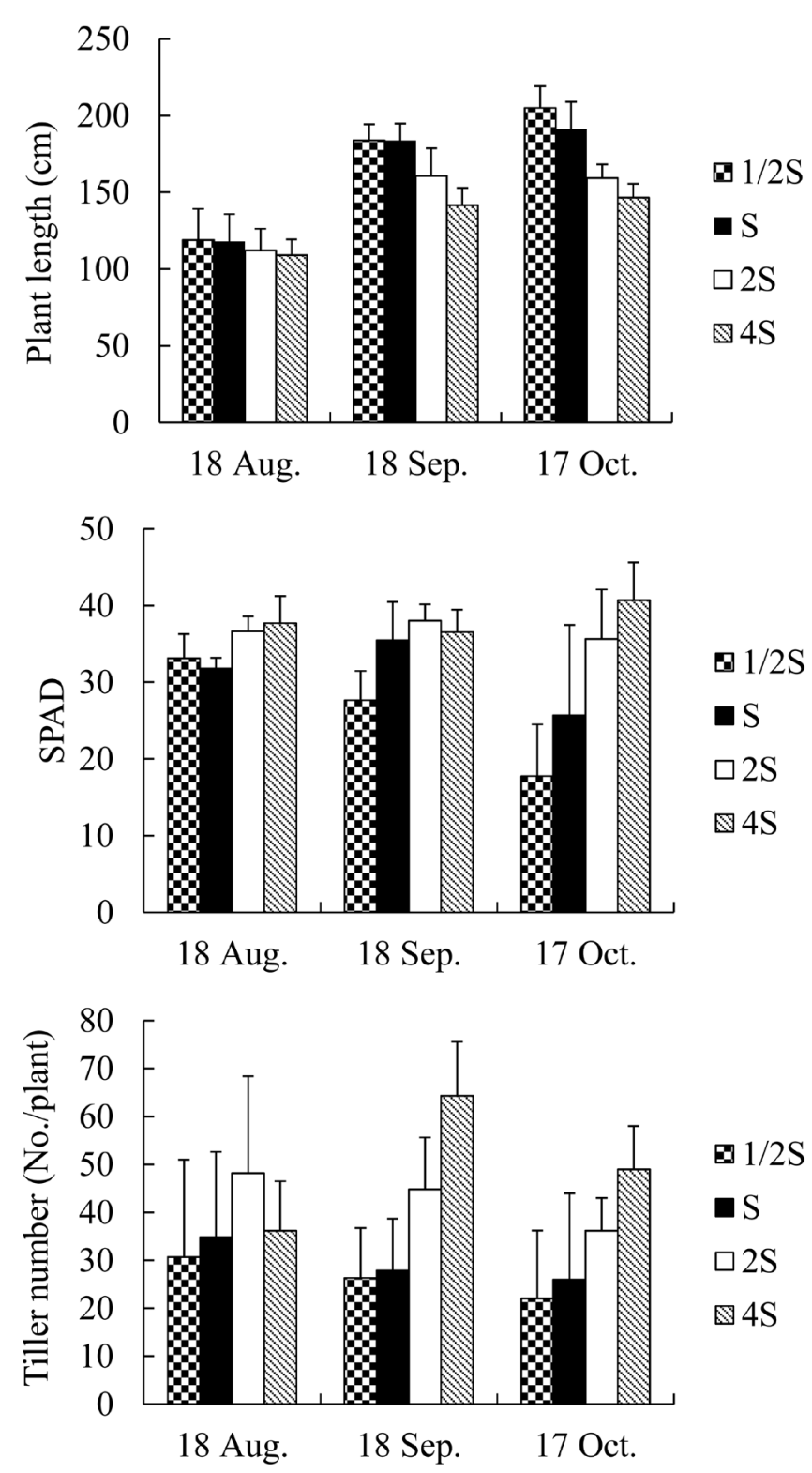

Figure 4. Plant length, SPAD index and tiller number of Eragrosis tef (teff) at several rates of fertilization (Exp. 2).

The available inorganic nutrient content in the $\mathrm{CF}+\mathrm{M}$ treatment was lower than in other fertilizer treatments. Therefore, the harvest index of teff in the $\mathrm{CF}+\mathrm{M}$ treatment tended to be lower than in the other treatments. The harvest index of rice, wheat and sorghum has been reported to be 43 [25], 37 [26] and 50\% [27], respectively. In the current experiment, the mean harvest index of teff across all treatments was $34 \%$, and in the DM treatment at high moisture was 38\%, demonstrating the potential use of this species as a forage crop in highly humid soil. The root biomass of perennial grasses is normally higher than those of annual crops, because it accumulates in the soil environment [23]. In Setaria, the $\mathrm{H}$ treatment decreased tiller number; this phenomenon may be due to self-thinning due to apical dominance of the mother tiller, which reduces the growth of tillers. In the reverse case under no apical dominance of prominent tillers, plants produce many tillers [28]. Teff is known to transport nutrients preferentially to grain and foliage fractions, rather than to the underground stem and root fractions. Therefore, the relationship between nitrogen input and dry matter weight in each plant fraction was evaluated for both Experiments 1 and 2, showing a positive relationship between nitrogen input and ear dry weight (Figure 7). 


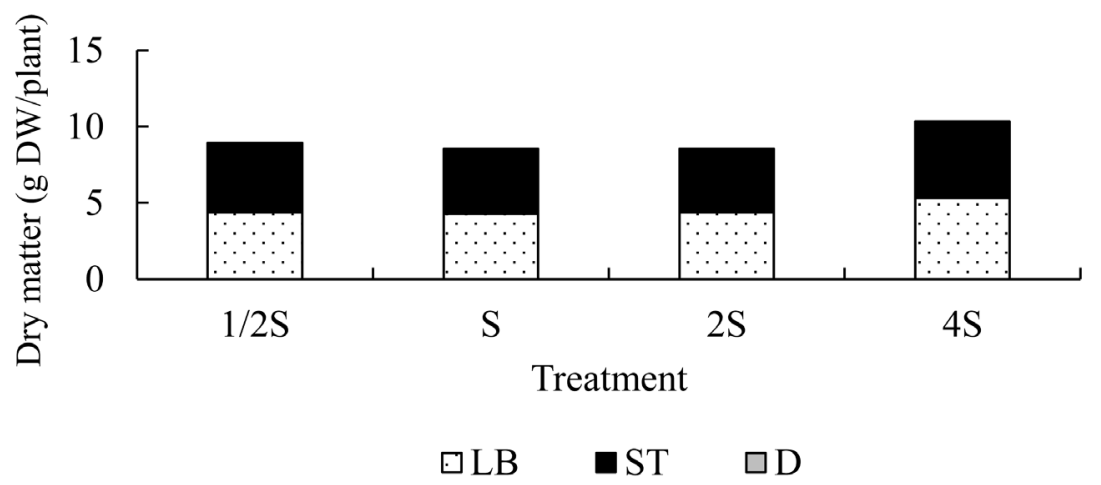

(a)

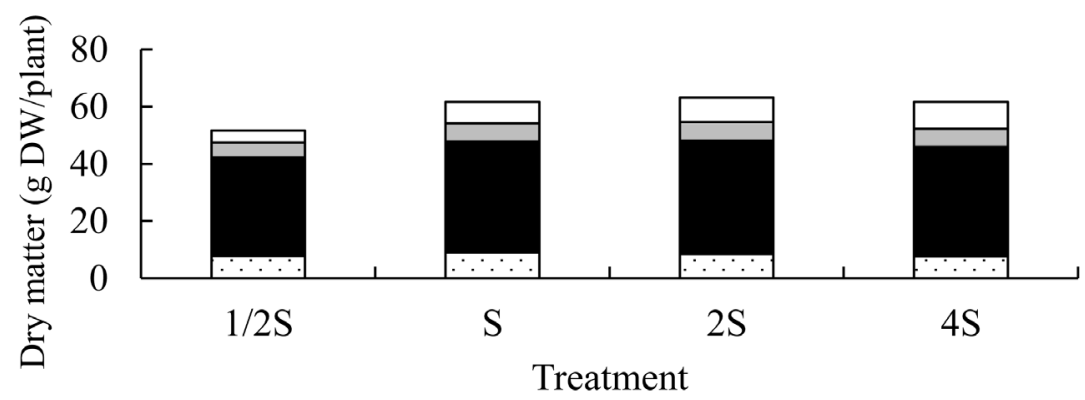

$\square \mathrm{LB} \square \mathrm{ST} \square \mathrm{D} \square \mathrm{E}$

(b)

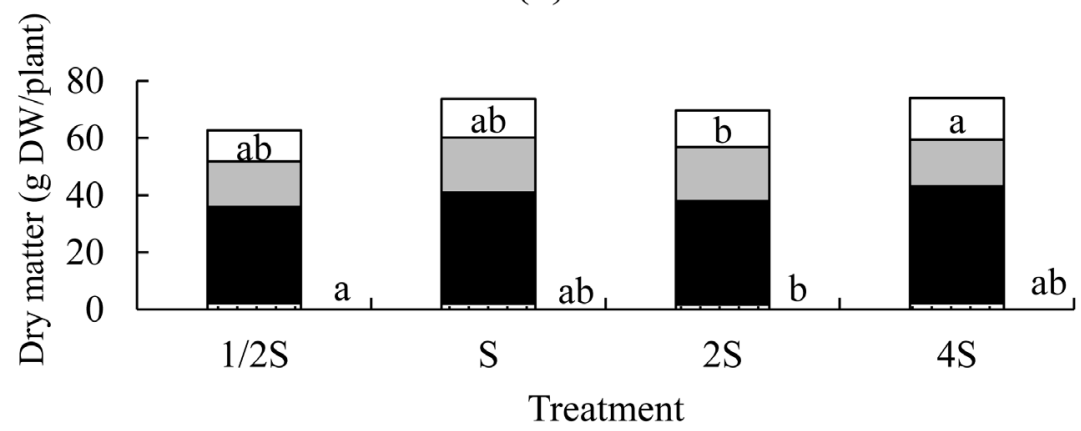

$\square \mathrm{LB} \square \mathrm{ST} \square \mathrm{D} \square \mathrm{E}$

(c)

Figure 5. Dry matter of plant fractions in Eragrosis tef (teff) at several rates of fertilization (Exp. 2). Plant fraction: leaf blade (LB), stem including leaf sheath (ST), dead parts (D), ear (E). Bars with different letters were different between treatments at the $5 \%$ level. (a) 18 Aug. (b) 18 Sep. (c) 17 Oct.

The response of plant growth to nitrogen fertilizer application was lower in teff than in other grasses [24], while the rate of nitrogen input significantly and positively affected ear dry weight in teff.

Hunter et al. (2007) [29] reported that the CP content of teff increased with an increase in fertilizer application, ranging from 120 to $170 \mathrm{mg} \cdot \mathrm{g}^{-1}$ under the optimum fertilizer application [22]. These CP contents of teff under the optimum fertilizer application was corresponded with the current results which showed that the CP content of teff in $4 \mathrm{~S}$ treatment was recorded at the same levels, except for lower level in D obtained in September. 


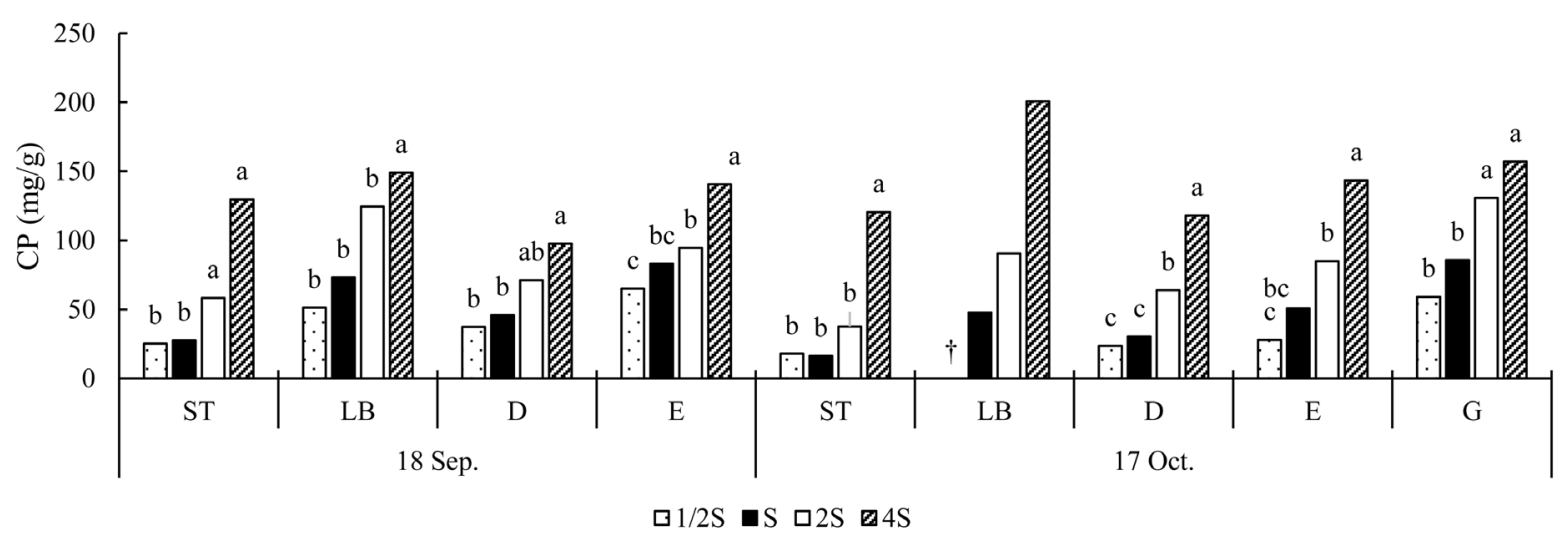

Figure 6. Crude protein content of plant fractions in Eragrosis tef (teff) at several rates of fertilization (Exp. 2). Plant fraction: leaf blade (LB), stem including leaf sheath (ST), dead parts (D), ear (E). Bars with different letters were different between treatments at the $5 \%$ level. ${ }^{\dagger}$ : Not determined.

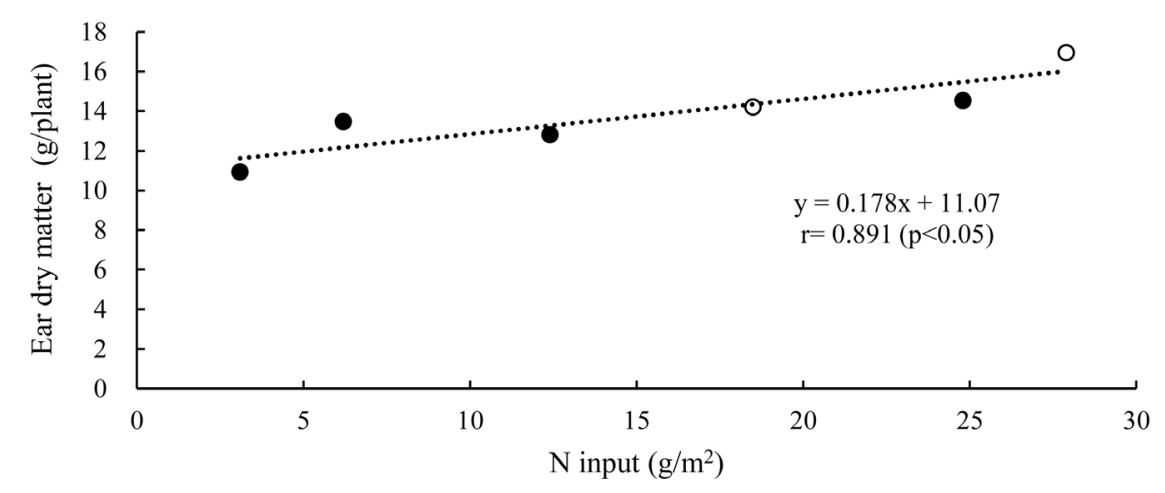

Figure 7. Relationship between nitrogen $(\mathrm{N})$ input and ear dry matter in both Exp. 1 and Exp. 2. Data: Exp. 1(०), Exp. $2(\bullet)$.

\section{Conclusion}

Teff was not significantly affected by high moisture treatment when compared with Setaria, except for CF + M treatment. The aboveground and underground dry matter weight and harvest index of teff were higher under high moisture treatment with DM application than the other treatments. Teff dry matter yield did not show any significant difference with an increase in chemical application rate. Therefore, the standard fertilizer level recommended for the cultivation of teff in the USA can be applied to cultivation of this grass in southern Kyushu, Japan, and teff has the potential for use as an early-harvest forage crop in the region.

\section{References}

[1] Bouwman, A.F. (1997) Long-Term Scenarios of Livestock-Crop-Land Use Interactions in Developing Countries. FAO Land and Water Bulletin 6. National Institute for Public Health and the Environment the Netherland.

http://www.fao.org/docrep/W5146E/w5146e00.htm\#Contents

[2] FAO (2009) The State of Food and Agriculture. FAO, Rome, 1-271.

[3] IPCC (2007) Contribution of Working Groups I, II and III to the Fourth Assessment Report of the Intergovernmental Panel on Climate Change, IPCC, Geneva, 1-104.

[4] Adiku, S.G.K., Narh, S., Jones, W., Laryea, K.B. and Dowuona, G.N. (2008) Short-Term Effects of Crop Rotation, Residue Management, and Soil Water on Carbon Mineralization in Tropical Cropping System. Plant and Soil, 311, 29-38. http://dx.doi.org/10.1007/s11104-008-9652-y

[5] Meza, F.J., Silva, D. and Vigil, H. (2008) Climate Change Impacts on Irrigated Maize in Mediterranean Climates: Evaluation of Double Cropping as an Emerging Adaptation Alternative. Agricultural Systems, 98, 21-30. http://dx.doi.org/10.1016/j.agsy.2008.03.005

[6] Yan, H., Fu, Y., Xiao, X., Huang, H.Q., He, H. and Ediger, L. (2009) Modeling Gross Primary Productivity for Winter 
Wheat-Maize Double Cropping System Using MODIS Time Series and $\mathrm{CO}_{2}$ Eddy Flux Tower Data. Agriculture, Ecosystems and Environment, 129, 391-400. http://dx.doi.org/10.1016/j.agee.2008.10.017

[7] Nakano, H., Hattori, I. and Morita, S. (2014) Yield and Nutritive Value Response to Low Spacing and Cultivar in Forage Rice. Grassland Science, 60, 55-62. http://dx.doi.org/10.1111/grs.12039

[8] Ministry of Agriculture, Forestry and Fisheries (MAFF) (2013) Shiro Wo Meguru Jousei. MAFF, Tokyo. http://www.maff.go.jp/j/chikusan/kikaku/lin/1_hosin/pdf/08_meguru_illust_all.pdf

[9] Hallu, T., Getachew, B. and Kebebew, A. (2008) Genetic Variation in $F_{2}$ Populations and Their Potential in the Improvement of Grain Yield in Tef (Eragrostis tef). Euphytica, 164, 105-111. http://dx.doi.org/10.1007/s10681-008-9655-z

[10] Ratchanee, P. (2009) The Potential for Growing Teff (Eragrostis tef [Zucc.] Trotter) in Thailand. Asian Journal of Food and Agro-Industry, S125-S131.

[11] Yenesew, M.Y., Abraham, M.H., Bart, S. and Teklu, E. (2013) Crop Water Productivity of Irrigated Teff in a Water Stressed Region. Water Resources Management, 27, 3115-3125. http://dx.doi.org/10.1007/s11269-013-0336-x

[12] Araya, A., Keesstra, S.D. and Stroosnijder, L. (2010) Simulating Yield Response to Water of Teff (Eragrostis tef) with FAO’s Aqua Crop Model. Field Crop Research, 116, 196-204. http://dx.doi.org/10.1016/j.fcr.2009.12.010

[13] Araya, A., Stroosnijder, L., Girmay, G. and Keesstra, S.D. (2011) Crop Coefficient, Yield Response to Water Stress and Water Productivity of Teff (Eragrostis tef Zucc.). Agricultural Water Management, 98, 775-783. http://dx.doi.org/10.1016/j.agwat.2010.12.001

[14] Delelegn, W. and Fassil, A. (2011) Effects of Plant Growth Promoting Rhizobacteria on Growth and Yield of Tef (Eragrostis tef Zucc. Trotter) under Greenhouse Condition. Research Journal of Microbiology, 6, 343-355. http://dx.doi.org/10.3923/jm.2011.343.355

[15] Roseberg, R.J., Norberg, S., Smith, J., Charlton, B., Rykbost, K. and Shock, C. (2006) Yield and Quality of Teff Forage as a Function of Varying Rates of Applied Irrigation and Nitrogen: Research in the Klamath Basin 2005. Annual Report. OSU-AES Special Report, 1069, 119-136.

[16] Seyfu, K. (1997) Teff. Eragrostis tef (Zucc.) Trotter. Promoting the Conservation and Use of Underutilized and Neglected Crops. Institute of Plant Genetic and Crop Plant Research, Gaterstleben/International Plant Genetic Resources Institute, Rome, 35. http://www.bioversityinternational.org/uploads/tx_news/Tef_Eragrostis_tef_Zucc._Trotter_279.pdf

[17] Ketema, S. (1997) Teff Eragrostis tef (Zucc.) Trotter. Bioversity International, Rome, 35.

[18] Miller, D. (2009) Teff Grass: A New Alternative. University of California Cooperative Extension. http://alfalfa.ucdavis.edu/+symposium/2009/files/talks/09WAS19_Miller_Tef.pdf\#search='Teff+grass\%EF\%BC\%9A A+new+alternative'

[19] Norberg, S., Roseberg, R., Charlton, B. and Shock, C. (2009) Teff. A New Warm Season Annual Grass for Oregon. Oregon State University Extension Service, Oregon. http://ir.library.oregonstate.edu/xmlui/bitstream/handle/1957/20545/em8970-e.pdf

[20] Stallknecht, G.F., Gilbertson, K.M. and Eckhoff, J.L. (1993) Teff: Food Crop for Humans and Animals. In: Janick, J. and Simon, J.E., Eds., New Crops, Wiley, New York, 231-234.

[21] Goto, I. and Minson, D.J. (1977) Prediction of the Dry Matter Digestibility of Tropical Grasses Using Pepsin-Cellulase Assay. Animal Feed Science and Technology, 2, 247-253. http://dx.doi.org/10.1016/0377-8401(77)90028-1

[22] Miller, D.R. (2011) Teff Grass Crop Overview and Forage Production Guide. 3rd Edition, Cal/West Seed Company, Woodland, CA. http://www.calwestseeds.com/products/teff/

[23] Bolinder, M.A., Angers, D.A., Belanger, G., Michaud, R. and Laverdiere, M.R. (2002) Root Biomass and Shoot to Root Ratios of Perennial Forage Crops in Eastern Canada. Canadian Journal of Plant Science, 82, 731-737. http://dx.doi.org/10.4141/P01-139

[24] Nishio, T., Sekiya, H. and Kogano, K. (1994) Transformations of Fertilizer Nitrogen in Soil-Plant System with Special Reference to Comparison between Submerged Conditions and Upland Field Condition. Soil Science and Plant Nutrition, 40, 1-8. http://dx.doi.org/10.1080/00380768.1994.10414272

[25] Cui, J., Kusutani, A., Toyota, M. and Asanuma, K. (2000) Studies on the Varietal Difference of Harvest Index in Rice. Relationship between Harvest Index and Dry Matter Production. Japanese Journal of Crop Science, 69, 351-358. http://dx.doi.org/10.1626/jcs.69.351

[26] Tanno, H. and Gotoh, K. (1983) Range of Variations of Harvest Index in Spring Wheat Varieties. Journal of the Faculty of Agriculture, Hokkaido University, 14, 56-63.

[27] Tsukuda, K. and Hoshino, M. (1978) The Effect of Density on Yield of Grain Sorghum. Journal of Japanese Society of Grassland Science, 24, 210-215. 
[28] Manske, L.L. (1998) General Description of Grass and Development and Defoliation Resistance Mechanisms. Annual Report Dickinson Research Extension Center. http://www.ag.ndsu.edu/archive/dickinso/research/1998/range98a.htm

[29] Hunter, M., Barney, P., Kilcer, T., Cherney, J., Lawrence, J. and Ketterings, Q. (2007) Agronomy Fact Sheet Series, Teff as Emergency Forage. Cornell University Cooperative Extension, Fact Sheet 24.

http://www.mccc.msu.edu/states/TEFFCornellfactsheet24.pdf\#search='Agronomy+Fact+Sheet+Series\%EF\%BC\%8CT eff+as+Emergency+Forage' 